\title{
Survival Analysis in Colon Cancer Patients
}

\section{Kolon Kanserli Hastalarda Yaşam Analizi}

\author{
๑Ayse Ulgen', ๑Sirin Cetin'2, ๑isa Dede ${ }^{3}$ \\ 'Girne American University Faculty of Medicine, Department of Biostatistics, Karmi, Cyprus \\ ${ }^{2}$ Gaziosmanpasa University Faculty of Medicine, Department of Biostatistics, Tokat, Turkey \\ ${ }_{3}^{3}$ Mustafa Kemal University Faculty of Medicine, Medical Oncology, Antakya, Turkey
}

\begin{abstract}
Introduction: The aim of this study is to investigate the degree of risk and significance of prognostic and demographic factors affecting the survival of patients diagnosed with colon cancer.

Material and Method: This was a retrospective study conducted by reviweing the medical records of 80 patients diagnosed with metastatic colon cancer at the Oncology Clinic at the Mustafa Kemal University between 01/2018-01/2021. Cox regression analysis was performed to determine the prognostic and demographic factors affecting the colon cancer and Kaplan-Meier method was used to estimate the overall survival. Difference between the variable levels in terms of survival probabilities was investigated using the log-rank test.

Results: The average age of the patients was $56.72 \pm 12.42$. The median survival time of patients with colon cancer was 48.42 months ( $95 \%$ confidence interval $(\mathrm{Cl})=41.97-54.87)$. Cox regression analysis showed that age, incident type 2 diabetes mellitus (DM), and family history of colon cancer were significantly associated with overall survival $(p<0.005)$. Patients with colon cancer aged 50 years; patients with $\mathrm{DM}$ and patients with a family history of colon cancer were approximately 3 times more at risk compared to patients over 50 years; patients without DM and patients without colon cancer in the family, consecutively.

Conclusion: The effect of prognostic and demographic factors affecting the survival of patients with colon cancer was evaluated. Our findings showed that age, DM and family history of colon cancer can be used to estimate the survial of patients with colon cancer. We believe that our results will help guide practitioners for the treatment of patients diagnosed with colon cancer.
\end{abstract}

Keywords: Colon cancer, prognostic and demographic factors, diabetes mellitus, survival analysis

\section{Öz}

Amaç: Bu çalışmanın amacı kolon kanseri tanısı almış hastaların sağkalımını etkileyen prognostik ve demografik faktörlerin risk derecesini ve önemini araşıtırmaktır.

Gereç ve Yöntem: Mustafa Kemal Üniversitesi Onkoloji Kliniği'nde 01/2018-01/2021 arasında metastaz kolon kanser tanısı almış 80 hastanın tıbbi kayıtları gözden geçirilerek yapılan retrospektif bir çalıșmadır. Kolon kanserini etkileyen prognostik ve demografik faktörleri belirlemek için Cox regresyon analizi yapıldı ve genel sağkalımı tahmin etmek için Kaplan-Meier yöntemi kullanıldı. Sağkalım olasılıkları açııından değişken düzeyler arasındaki fark, log-rank testi kullanılarak araştııldı.

Bulgular: Hastaların ortalama yaşı 56,72 $\pm 12,42$ idi. Kolon kanseri olan hastaların medyan yaşam süresi 48,42 aydı (\% 95 güven aralığı $(C I)=41,97-54,87)$. Cox regresyon analizi, yaş, tip 2 diyabetes mellitus (DM) ve ailede kolon kanser öyküsünün genel sağkalım ile anlamlı şekilde ilişkili olduğunu gösterdi $(p<0,005) .50$ yaş ve üzeri kolon kanser hastalarl; DM'li hastalar ve ailesinde kolon kanser öyküsü olan hastalar, sırasıyla <50 yaşındaki hastalara; DM olmayan hastalara ve ailesinde kolon kanseri olmayan hastalara kıyasla yaklaşık 3 kat daha fazla risk altındaydı.

Sonuç: Kolon kanserli hastaların sağkalımını etkileyen prognostik ve demografik faktörlerin etkisi değerlendirildi. Bulgularımı kolon kanserli hastaların yaş, DM ve aile öyküsünün kolon kanserli hastaların sağkalımlarını tahmin etmek için kullanılabileceğini gösterdi. Sonuçlarımızın, metastatik kolon kanser teşhisi konan hastaların tedavisi için klinisyenlere rehberlik edeceğine inanıyoruz.

Anahtar Kelimeler: Kolon kanseri, prognostik ve demografik faktörler, diyabetes mellitus, yaşam analizi 


\section{INTRODUCTION}

Colon cancer is a disease that can be prevented if detected during the period when preceding histopathological findings are monitored, and can be treated if diagnosed early. Colon cancer is an important cause of mortality and morbidity in the world and in our country. Despite advanced treatment options, colon cancer is still an important cause of mortality. Colon cancer is the $3^{\text {rd }}$ most common cancer in the world in general. ${ }^{[1-3]}$ If we look at the incidence of the most frequently seen cancer types in Turkey, it ranks $3^{\text {rd }}$ among women and $4^{\text {th }}$ in men. ${ }^{[4]}$ According to the International Cancer Research Agency (IARC), an increase in colon cancer incidence is expected by $2040 .{ }^{[5]}$ Although the incidence of colon cancer has increased in recent years, significant improvements have been made in cancer-related survival thanks to advances in early diagnosis and treatment. ${ }^{[1]}$ Since colon cancer is a heterogeneous disease, the natural course of the disease varies between patients. In the literature, a relationship has been found between smoking, genetic factors, eating habits, sedentary lifestyle, abdominal adiposity and colon cancer. In addition, family history of colon cancer, inflammatory bowel disease, diabetes mellitus (DM), obesity, and consumption of highly processed red meat increase the risk of developing colon cancer. It is suggested that consumption of fruits, vegetables and fish reduces the risk of developing colon cancer ${ }^{[1]}$ In addition, a relationship between waist-to-hip ratio and colon cancer has been found in the literature and it has been reported to be inversely related to colon cancer in physical activity. ${ }^{[6-13]}$

There have been several studies investigating the effect of the degree of risk and significance of prognostic and demographic factors affecting the survival of patients diagnosed with colorectal cancer and colon cancer. ${ }^{[14-16]}$ However, there are limited number of studies conducted on the Turkish population. ${ }^{[17-22]}$

The aim of this study is to investigate prognostic factors affecting the survival of patients with colon cancer in a Turkish population. The main purpose of survival analysis is to determine the prognostic factors affecting the hazard function.

\section{MATERIAL AND METHOD}

\section{Case Selection Criteria}

The study was a retrospective one. Medical records of 80 patients diagnosed with colon cancer were reviewed at the Oncology Clinic of the Mustafa Kemal University Faculty of Medicine between 01/2018-01/2021 and were included in the study. Colon cancer patients with a performance score of 0 to 1 were included in the study, and all patients with metastases received chemotherapy. Retrospectively, patient files were scanned, and all patients' age, gender, date of diagnosis, pathological stage, metastasis status, alcohol, smoking, DM history, family history of colon cancer, obesity status, death dates, and the latest polyclinic control dates for those who were alive were determined.

\section{Statistical Model}

\section{Cox Regression Analysis}

Cox regression is widely used to model survival analysis data. ${ }^{[23,24]}$ For the Cox regression model;

Let $\mathrm{X} 1, \mathrm{X} 2, \ldots, \mathrm{Xp}$ be $\mathrm{p}$ explanatory variables and $\mathrm{x} 1, \mathrm{x} 2, \ldots, \mathrm{xp}$ be the values of these variables. In the Cox regression model, the set of explanatory variables is the vector $x=(x 1, x 2, \ldots, x p)$ and $\mathrm{h} 0(\mathrm{t})$ is the basic hazard function, i. hazard function for the unit is the following:

$$
\mathrm{h}_{\mathrm{i}}(\mathrm{t})=\mathrm{h}_{0}(\mathrm{t}) \Psi\left(\mathrm{x}_{\mathrm{i}}\right) \quad(\mathrm{i}=1,2, \ldots, \mathrm{p})
$$

where $\Psi\left(\mathrm{x} \_\mathrm{i}\right) \mathrm{i}$. unit is a function of the explanatory variables vector.

$\psi\left(x_{\mathrm{i}}\right)=\exp \left(\beta_{1} x_{1}+\beta_{2} x_{2}+\cdots+\beta_{p} x_{p}\right)$

$\beta_{\text {_it's }}$ are defined as regression coefficients. So the Cox regression model is;

$h_{i}(t)=h_{0}(t) \exp \left(\beta_{1} x_{1 i}+\beta_{2} x_{2 i}+\cdots+\beta_{p} x_{p i}\right)$

The most important feature of this equation, which includes the proportional hazards assumption, is that the basic hazard function is a function of $t$. This model is;

$\log \left\{\frac{h_{i}(t)}{h_{0}(t)}\right\}=\beta_{1} x_{1 i}+\beta_{2} x_{2 i}+\cdots+\beta_{p} x_{p i}$

Rearranging the model, the Cox regression model can also be expressed as the linear component for the logarithm of the hazard ratio.

When there is no explanatory variable in the Cox regression model;

$h(t)=h_{0}(t) \exp \left(\sum_{j=1}^{p} \beta_{j} x_{j}\right)=h_{0}(t) \exp (0)=h_{0}(t)$

It is reduced to the basic hazard function in the form above.

\section{Proportional Hazard}

The proportional hazard assumption is that the hazard ratio is constant versus time. In other words, it means that the hazard function of an individual is proportional to the hazard function of another individual.

$x^{*}=\left(x_{1}^{*}, x_{2}^{*}, \ldots, x_{p}^{*}\right)$ ve $x=\left(x_{1}, x_{2}, \ldots, x_{p}\right)$ are vectors of explanatory variables belonging to two individuals and the hazard ratio is:

$\theta=\frac{\hat{h}\left(t, x^{*}\right)}{\hat{h}(t, x)}=\frac{\hat{h}_{0}(t) \exp \left(\sum_{j=1}^{p} \hat{\beta}_{1} x_{j}^{*}\right)}{\hat{h}_{0}(t) \exp \left(\sum_{j=1}^{p} \hat{\beta_{1}} x_{j}\right)}=\frac{\exp \left(\sum_{j=1}^{p} \hat{\beta}_{1} x_{j}^{*}\right)}{\exp \left(\sum_{j=1}^{p} \hat{\beta_{1}} x_{j}\right)}=\exp \left(\sum_{j=1}^{p} \hat{\beta}_{1}\left(x_{j}^{*}-x_{j}\right)\right)$

This expression is a mathematical expression that shows the proportional hazard assumption. The proportional hazard conjecture can also be expressed as;

$\hat{\mathrm{h}}\left(\mathrm{t}, \mathrm{x}^{*}\right)=\hat{\theta} \hat{\mathrm{h}}(\mathrm{t}, \mathrm{x})$

In this expression $\hat{\theta}$, is expressed as the proportionality constant and is independent of time. 
The most important assumption of the Cox regression model is the proportional hazard assumption. Hazard rates are constant over the entire time. For the validity of this assumption, proportionality needs to be examined. The methods used to test the proportional hazard assumption are graphical and numerical methods. ${ }^{[25]}$

\section{Data and Statistical Analyses}

To investigate the effects of prognostic factors on survival, Log-rank test and Kaplan-Meier method for drawing survival curves were used. First, life probabilities were estimated with the Kaplan-Meier method and log-rank test was performed to see if there was a difference between the variable levels in terms of survival probabilities. Then, Cox regression analysis was performed to determine the factors affecting the recurrence of the disease. SPSS (version 21; IBM, Armonk, NY) package program was used for statistical analysis. $P$ values of less than 0.05 were regarded as statistically significant.

\section{Ethics Committee Approval}

Ethics committee approval was obtained from the Ethics Committee of Mustafa Kemal University Faculty of Medicine (2020/13). Informed consent was not necessary as the study is a retrospective one.

\section{RESULTS}

Of the 80 patients included in the study, 51 (63.7\%) were male and $29(36.3 \%)$ were female. The age of the patients at the time of diagnosis ranged between $30-87$, and the mean age was $56.72 \pm 12.42$. The average age of men was $56 \pm 12.78$, and the average age of women was $58.58 \pm 11.98$.

The median overall survival of 80 colon cancer patients included in our study was 48.42 months (95\% confidence interval; 41.97-54.87). Kaplan-Meier survival curve obtained for the patients is shown in Figure 1.

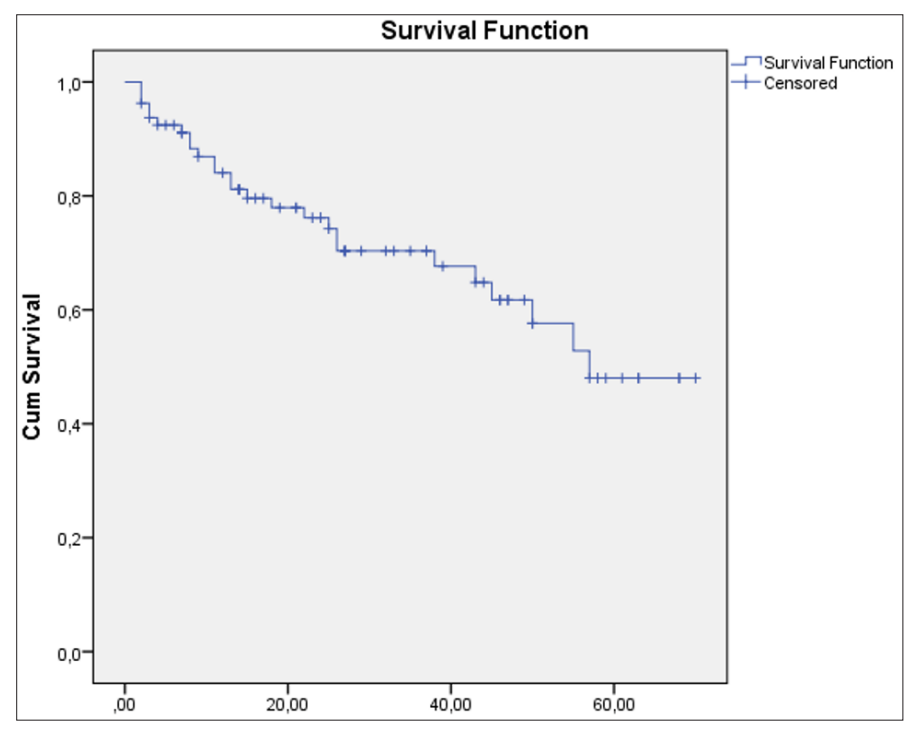

Figure 1. Overall survival curve for all patients
Median overall survival for colon cancer patients $\geq 50$ years was found to be 44 months $(95 \% \mathrm{Cl} 36.56-52.88)$. Overall survival median for colon cancer patients $<50$ years of age was 53 months, (95\% Cl 44.33-62.89). No statistically significance was observed between age and overall survival time (Figure 2).

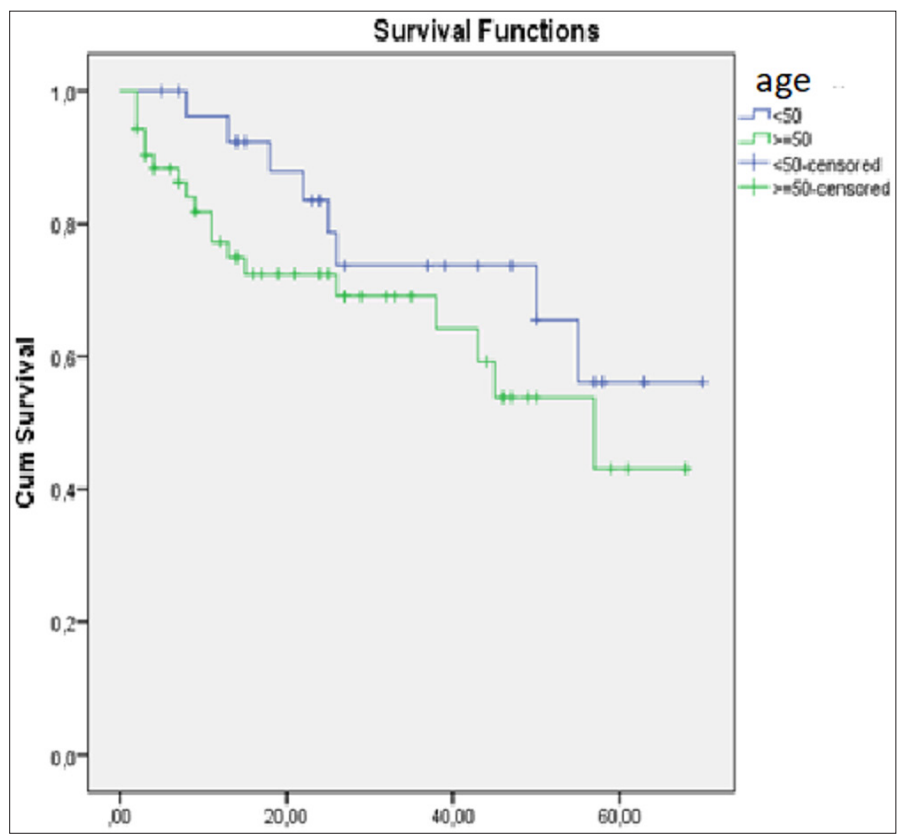

Figure 2. Survival curve by age

The median overall survival in colon cancer patients with colon cancer in their family was found to be 26 months (95\% Cl 19.91-39.40) (Figure 3). Family history of colon cancer and overall survival was statistically significant $(p=0.001)$ (Table 1).

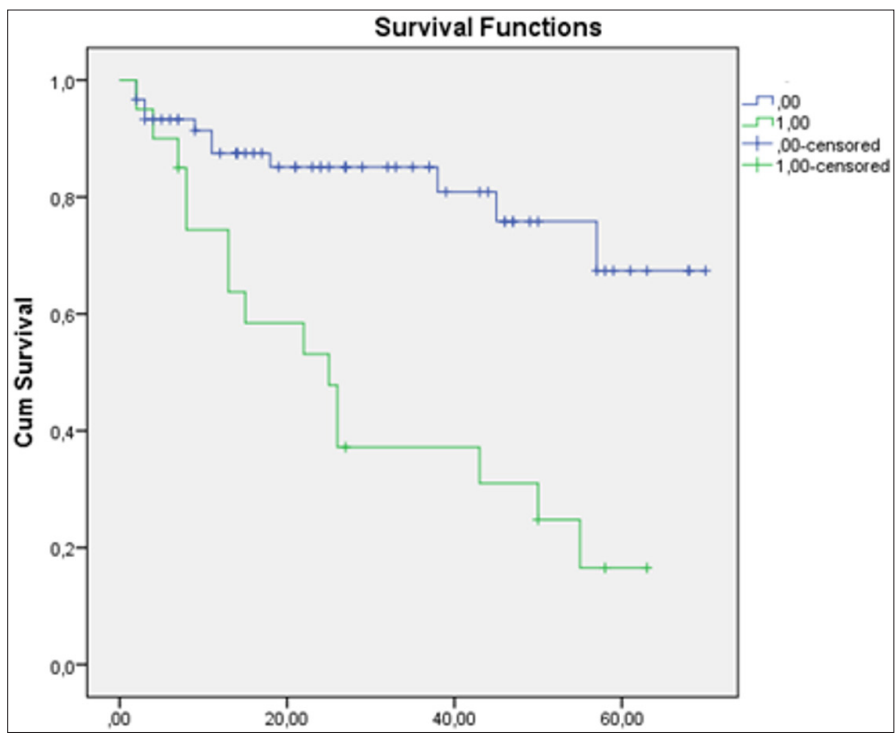

Figure 3. Survival curve by family colon cancer status 
Table 1. Kaplan-Meier results

\begin{tabular}{lcccc} 
Factor & $\begin{array}{c}\text { Factor } \\
\text { Level }\end{array}$ & Standard E. & Median Survival Month & p \\
\hline \multirow{2}{*}{ Gender } & Woman & 3.99 & $47.1(39.27-54.92)$ & 0.560 \\
& Man & 5.04 & $46.8(36.99-56.78)$ & \\
\hline \multirow{2}{*}{ Age } & $<50$ & 4.73 & $53.61(44.33-62.89)$ & 0.201 \\
& $\geq 50$ & 4.16 & $44.72(36.56-52.88)$ & \\
\hline \multirow{2}{*}{ Diabetes } & No & 3.35 & $49.94(43.36-56.52)$ & \multirow{2}{*}{0.100} \\
& Yes & 10.54 & $30.14(9.48-50.80)$ & \\
\hline \multirow{2}{*}{ Family } & No & 3.48 & $57.05(50.33-63.77)$ & \multirow{2}{*}{0.001} \\
\hline \multirow{2}{*}{ Alcohol } & Yes & 4.97 & $29.65(19.91-39.40)$ & \\
& Yok & 3.35 & $49.04(42.46-55.60)$ & \multirow{2}{*}{0.420} \\
\multirow{2}{*}{ Smoking } & Var & 9.14 & $28.12(10.20-46.04)$ & \\
& Yok & 4.54 & $46.49(37.58-55.40)$ & \multirow{2}{*}{0.560} \\
\hline
\end{tabular}

The median overall survival in non-diabetic colon cancer patients was found to be 50 months ( $95 \% \mathrm{Cl}$ 43.36-56.52). Median overall survival in patients with DM but without colon cancer was found to be 30 months ( $95 \% \mathrm{Cl}$ 9.48-50.80) (Figure 4). No statistical significance was found between diabetic colon cancer patients and overall survival $(p=0.10)$ (Table 1).

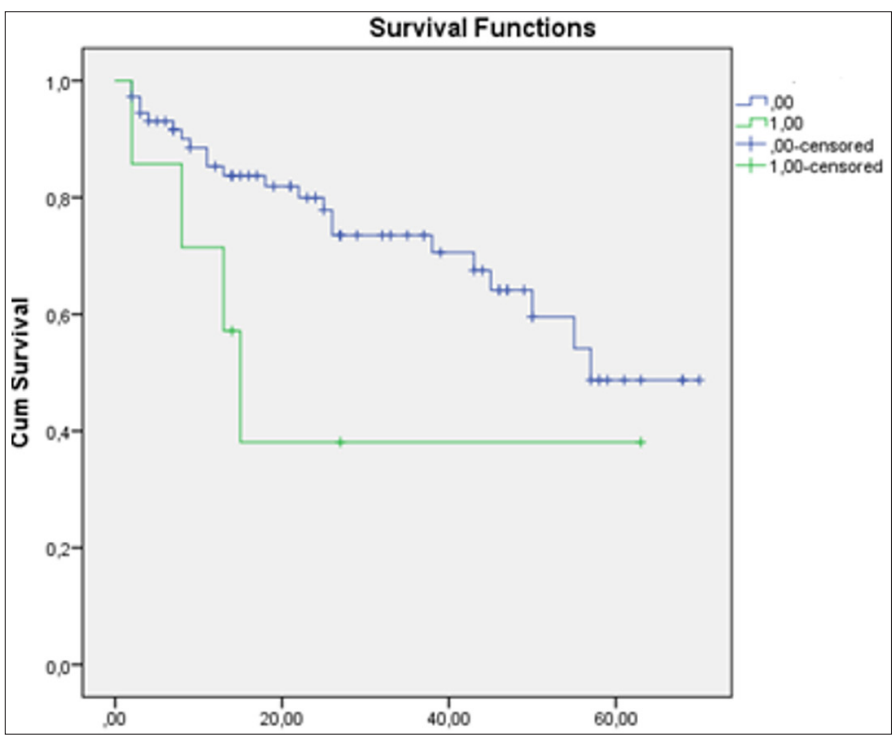

Figure 4. Survival curve according to having diabetes

In this study, the effect of explanatory variables on life span is investigated. Cox regression analysis which is generally used for survival analyses was used. To use the Cox regression model, variables must satisfy the proportional hazards assumption. The proportional hazard assumption was examined with the Schoenfed residuals; rank of life span was examined with the correlation test. As a result, it was seen that the proportional hazard assumption was satisfied $(p=0.570)$. In the Cox regression analysis, the initial levels of the variables were taken as the baseline level.
Cox regression analysis was used for the survival of colon cancer patients by evaluating prognostic factors. Age, DM, family history of cancer were found to be associated with survival (Table 2).

Additionally, it was observed that colon cancer patients who are $\geq 50$ years of age are 3 times more at risk than patients $<50$ years. Patients with DM are 3 times more at risk than those without DM. Patients with a family history of colon cancer are approximately 3 times more at risk than those without colon cancer in the family. (Table $\mathbf{2}$ ).

\begin{tabular}{lccccccc} 
Table 2. Cox Analyses results & & & & & \\
Factor & & SE & $\mathbf{z}$ & Exp( $\boldsymbol{\beta})$ & $\begin{array}{c}\text { \%95 } \\
\text { Confidence } \\
\text { Interval }\end{array}$ & p value \\
\hline Gender & $\begin{array}{c}\text { Woman } \\
\text { Man }\end{array}$ & $\begin{array}{c}\text { ref } \\
0.450\end{array}$ & 0.008 & 0.962 & 0.398 & 2.325 & 0.931 \\
\hline Age & $<50$ & ref & & & & & \\
\hline Diabetes & No & ref & & & & & \\
& Yes & 0.775 & 5.075 & 3.735 & 1.255 & 26.210 & 0.024 \\
\hline Family & No & ref & & & & & \\
History & Yes & 0.445 & 21.309 & 3.795 & 3.260 & 18.642 & $\mathrm{p}<0.001$ \\
\hline Smoking & No & ref & & & & & \\
& Yes & 0.423 & 0.192 & 1.204 & 0.526 & 2.756 & 0.661 \\
\hline Alcohol & No & ref & & & & & \\
& Yes & 0.758 & 0.438 & 1.652 & 0.374 & 7.304 & 0.508 \\
\hline
\end{tabular}

\section{DISCUSSION}

In our study, a significant association was found between colon cancer and age $(p=0.003)$. In a Korean study conducted with 5086 subjects Choe et al. reported that advanced age is an increased risk for colon cancer development. ${ }^{[26]}$ In most studies in the literature, incidence of colon cancer is observed to increase with age. If there is no family history of colon cancer in the family, colon cancer is rarely seen at an early age. ${ }^{[27]}$

In our study, a moderately significant association was observed between colon cancer and DM $(p=0.024)$. Several studies found a significant association and increased risk of type $2 \mathrm{DM}$ and colon cancer. ${ }^{[12-15,28-30]} \mathrm{A}$ meta analyses conducted by between 1966 and 2005 revealed a strong relationship between DM and increased risk of colon cancer and rectal cancer in both men and women. ${ }^{[31]} \mathrm{A}$ more recent systematic review with trend analysis of 203 cohorts indicated that subjects with diabetes have an increased risk of several cancers and the relative risk of cancer incidence (including colorectal and colon cancer) associated with diabetes increased until 2000 and between 2000 and 2010, the relative risk of colorectal cancer incidence was observed as 1.2. ${ }^{[12]}$ Additionally, a recent study showed that diabetes may significantly increase the risk of colorectal cancer, especially in patients aged $45-64$ years. ${ }^{[32]} \mathrm{Ma} Y$ et 
al. followed 87,523 women between 1980-2012 and 47,240 men between 1986-2012 from two large US cohorts. Among men, DM was associated with increased risk of colorectal cancer compared to those without DM with an increased risk of 1.42. Among women, DM was also found to be positively, but not statistically associated with colorectal cancer risk. ${ }^{[33]}$

To our knowledge there are only a limited number of studies conducted to investigate the effect of prognostic and demographic factors on the risk of survival of colorectal and colon cancer patients in the Turkish population. Bekar E. investigated the relationship between survival and prognostic factors in 35 cases with colorectal carcinoma between 19851996. ${ }^{[17]}$ In another study conducted with 126 colorectal patients at the Firat University Hospital between 1994 and 2005, multivariate analysis showed that stage of cancer, extent of bowel wall penetration and distant metastasis were independent prognostic factors for both overall survival and disease free survival. ${ }^{[18]}$ Eker $B$ et al. studied 116 Turkish patients with metastatic colorectal cancer; it was observed that among those who benefited from first-line therapy, had history of metastasectomy, were K-RAS wild type and had low CA 19-9 levels before the first-line therapy, showed better prognosis independent of other factors. ${ }^{[19]}$ Cetin $B$ et al. conducted a study for 170 patients between 2006 and 2010 with metastatic colorectal cancer and showed that serum $\mathrm{LDH}$ and neutrophil levels were the main prognostic factors in predicting survival, followed by progression free survival. ${ }^{[20]}$ Orun $Y$ studied the lifetime risk of developing cancer in Turkey in men and women as well as the risk for those less than 65 years olds. Lifetime risk of developing colon cancer in Turkey was reported as 3.79-3.86 and 1.34-1.35 until 65 years old. In men, these percentages were 4.22-4.32 and 1.49 and in women as 3.36-3.41 and 1.20 respectively. ${ }^{[21]}$ Kalcan $S$ et al. compared the survival in surgically treated rectum and colon cancers and determined the factors affecting survival with 161 patients. They concluded that even though the location of colorectal cancers showed no significant effect on survival, early tratment increased the survival rate significantly. ${ }^{[22]}$

To our knowledge, there aren't any studies that show association between colon cancer and DM in the Turkish population. In our study, we also observed that patients with colon cancer in the family were 3 times more at risk compared to those who did not have family members with colon cancer. As also stated in the literature and consistent with our findings, we observed thar the risk of developing colon cancer increases 2-fold in individuals with colon cancer in their family. ${ }^{[34]}$ Although no significant relationship was found between alcohol and colon cancer in our study, many studies in the literature stated that excessive alcohol consumption increases the risk of colon cancer approximately 3 times. ${ }^{[7,8,35]}$

Our study has certain limitations. It would be helpful to use multi-centric datasets with multiple statistical analyses with larger samples.

\section{CONCLUSION}

Our findings on the study of colon cancer patients are generally consistent with the literature. It can be stated that age, DM, family history of colon cancer are related to survival in colon cancer.

\section{ETHICAL DECLARATIONS}

Ethics Committee Approval: Ethics committee approval was obtained from the Ethics Committee of Mustafa Kemal University Faculty of Medicine (2020/13).

Informed Consent: Because the study s a retrospective one, no informed consent was taken from the patients.

Conflict of Interest: Authors have no conflict of interest to declare.

Financial Disclosure: Authors declare that this study has received no financial support.

Author Contributions: Concept: AÜ, ŞÇDesign: AÜ, ŞÇ Data Collection and Processing: ID Analysis and Interpretation: ŞÇ, AÜ, ID Literature Search: AÜ, ID.

\section{REFERENCES}

1. Sung H, Ferlay J, Siegel RL, et al. Global cancer statistics 2020: GLOBOCAN estimates of incidence and mortality worldwide for 36 cancers in 185 countries. CA Cancer J Clin. 2021;10.3322/caac.21660.

2. Dekker E, Tanis PJ, Vleguels JLA, Kasi PM, Wallace MB. Colorectal Cancer. Lancet 2019;394(10207):1467-80.

3. Boyle P., Leon ME. Epidemiology of colorectal cancer. Br Med Bull 2002;64(1):25-6.

4. Mollahaliloğlu S, Başara BB, Eryılmaz Z. TC Sağlık Bakanlığı Sağlık İstatistikleri Yıllığı. Ankara: Kalkan Matbaacılık, 2010;1-100.

5. International Agency For Research On Cancer, CancerTomorrow. Available from: http://gco.iarc.fr/tomorrow/graphic-line?type=0\&population=9 $00 \&$ mode $=$ population \&sex=0\&cancer=39\&age_group=value\&apc male=0\&apc_female=0. Accessed on 20th October 2020.

6. Otake S, Takeda H, Suzuki Y, et al. Association of visceral fat accumulation and plasma adiponectin with colorectal adenoma: evidence for participation of insulin resistance. Clin Cancer Res. 2005;11(10):3642-6.

7. Giovannucci E, Ascherio A, Rimm EB, Colditz GA, Stampfer MJ, Willett WC. Physical activity, obesity, and risk for colon cancer and adenoma in men. Ann Intern Med. 1995;122(5):327-34.

8. Thanikachalam K, Khan G. Colorectal Cancer and Nutrition. Nutrients 2019; $11(1): 164$.

9. Carr PR, Weigl K, Edelmann D, et al. Estimation of Absolute Risk of Colorectal Cancer Based on Healthy Lifestyle, Genetic Risk, and Colonoscopy Status in a Population-Based Study. Gastroenterol 2020;159(1):129-38.

10. Recio-Boiles A, Cagir B. Colon Cancer. In: StatPearls. Treasure Island (FL): StatPearls Publishing; January 25, 2021.

11. Martina Nebbia 1, Nuha A Yassin 1, Antonino Spinelli. Colorectal Cancer in Inflammatory Bowel Disease. Clin Colon Rectal Surg 2020;33(5):305-17.

12. Ling S, Brown K, Miksza JK, et al. Risk of cancer incidence and mortality associated with diabetes: A systematic review with trend analysis of 203 cohorts. Nutr Metab Cardiovasc Dis 2021;4:31(1):14-22.

13. Luo W, Cao Y, Liao C, Gao F. Diabetes mellitus and the incidence and mortality of colorectal cancer: a meta-analysis of 24 cohort studies Colorectal Dis 2012;14:1307-12 
14.Zhu B, Wu X, Wu B, Pei D, Zhang L, Wei L. The relationship between diabetes and colorectal cancer prognosis: $A$ meta-analysis based on the cohort studies. PLoS One. 2017;12(4):e0176068.

15.Gao RZ, Gu J, Du CZ, Li M. [Impact of diabetes mellitus on clinicopathological factors and prognosis of patients with colorectal cancer]. Zhonghua Wai Ke Za Zhi. 2010;48(2):88-92.

16. Rasouli MA, Moradi G, Roshani D, Nikkhoo B, Ghaderi E, Ghaytasi B. Prognostic factors and survival of colorectal cancer in Kurdistan province, Iran A population-based study (2009-2014). Medicine (Baltimore). 2017; 96(6): e5941.

17. Bekar $E$. The relationship between survival and the prognostic factors in colorectal carcinomas. Turkiye Ekopatoloji Derg 2000; 6(1-2):5-11

18. Türkoğlu A, Çetinkaya Z , GirginM , Ayten R, Kanat BH , Binnetoğlu K. Prognostic factors in colorectal cancers. Dicle Medical J. 2014;41(4):72431

19. Eker B, Ozaslan E, Karaca H, et al. Factors Affecting Prognosis in Metastatic Colorectal Cancer Patients. Asian Pac J Cancer Prev 2015;16(7):3015-21.

20. Cetin B, Kaplan MA, Berk V, et al. Prognostic factors for overall survival in patients with metastatic colorectal carcinoma treated with vascular endothelial growth factor-targeting agents. Asian Pac J Cancer Prev. 2012;13(3):1059-63.

21. Orun Y. Lifetime Risk of Developing Cancer in Turkey. Sosyal Guvence Derg 2017;6(12):108-24.

22. Kalcan $S$, Sisik $A$, Basak $F$, et al. Evaluating factors affecting survival in colon and rectum cancer: A prospective cohort study with 161 patients. J Can Res Ther 2018;14(2);416-20.

23. Cox DR. Regression models and Life-Tables. Breakthroughs in statistics. Springer Series in Statistics, New York, NY, 1992. 527-541.

24. Lee ET, Go OT. Survival analysis in public health research. Annu Rev Public Health 1997;18:105-34.

25. Therneau TM, grambsch PM Modelling Survival Data: Extending the Cox Model. (1st Ed), Springer, New York, 2000; 1-229

26. Choe JW, Chang HS, Yang SK, et al. Screening colonoscopy in asymptomatic average risk Koreans: Analysis in relation to age and sex. Journal of gastroenterology and hepatology 2007;22(7):1003-8.

27. Von Herbay, A, Sieg, B, Otto HF. Solid-cystic tumour of the pancreas. Virchows Archiv A Pathol Anat 1990; 416(6): 535-8.

28. Wojciechowska J, Krajewski W, Bolanowski M, Kręcicki T, Zatoński T. Diabetes and Cancer: a Review of Current Knowledge. Exp Clin Endocrinol Diabetes 2016;124(5):263-75.

29. Miłek T, Forysiński K, Myrcha P, Ciostek P. Diabetes association of polyps and colon cancer. Pol Przegl Chir 2019;28;91(4):9-12.

30.González N, Prieto I, Del Puerto-Nevado L, et al. 2017 update on the relationship between diabetes and colorectal cancer: epidemiology, potential molecular mechanisms and therapeutic implications. Diabetes Cancer Connect Consortium. Oncotarget. 2017;14;8(11):18456-85.

31. Larsson SC, Orsini N, Wolk A. Diabetes mellitus and risk of colorectal cancer: a meta-analysis. J Natl Cancer Inst. 2005;97(22):1679-87.

32. Chen HF, Chen P, Su YH, Su HF, Li CY. Age- and sex-specific risks of colorectal cancers in diabetic patients. Tohoku J Exp Med 2012;226(4):259-65.

33. Ma Y, Yang W, Song $M$, et al. Type 2 diabetes and risk of colorectal cancer in two large U.S. prospective cohorts Br J Cancer 2018;119(11):1436-42.

34. La Vecchia C, Negri E, Franceschi S, Gentile A. Family history and the risk of stomach and colorectal cancer. Cancer. 1992;70(1):50-5.

35. Garland C, Shekelle RB, Barrett-Connor E, Criqui MH, Rossof AH, Paul O. Dietary vitamin $\mathrm{D}$ and calcium and risk of colorectal cancer: a 19-year prospective study in men. Lancet. 1985;1(8424):307-9. 